\title{
PEDAGOGY
}

\section{METHODS OF EFFECTIVE ORGANIZATION OF TEACHING OF MATHEMATICS BY USING THE PROBLEM-BASED TEACHING}

\author{
Ilkhom Makhmudovich Zulfikharov, \\ Andijan branch of Tashkent State Agrarian University of the Republic of Uzbekistan, \\ Ibaydullaev Tulanboy, \\ Andijan State University of the Republic of Uzbekistan
}

DOI: https://doi.org/10.31435/rsglobal_ijitss/30122019/6853

\section{ARTICLE INFO}

Received 12 October 2019

Accepted 14 December 2019

Published 30 December 2019

\section{KEYWORDS}

teaching process, modern teaching methods, teaching methods and techniques, effective organization of teaching, teacher professionalism, comparative analysis, content and essence of problem-based teaching, cognitive activity, student's independent learning.

\begin{abstract}
In this article: strengthening the material-technical and informational base of higher education institutions, further improving the quality of teaching and learning processes in mathematics and independent learning by providing highquality educational literature, modern teaching methods and educational technologies; the stages of changing of the student's perceptual activity related to solve problematic situations in the effective organization of math classes are analyzed.
\end{abstract}

Citation: Ilkhom Makhmudovich Zulfikharov, Ibaydullaev Tulanboy. (2019) Methods of Effective Organization of Teaching of Mathematics by Using the Problem-Based Teaching. International Journal of Innovative Technologies in Social Science. 9(21). doi: 10.31435/rsglobal_ijitss/30122019/6853

Copyright: (C) 2019 Ilkhom Makhmudovich Zulfikharov, Ibaydullaev Tulanboy. This is an openaccess article distributed under the terms of the Creative Commons Attribution License (CC BY). The use, distribution or reproduction in other forums is permitted, provided the original author(s) or licensor are credited and that the original publication in this journal is cited, in accordance with accepted academic practice. No use, distribution or reproduction is permitted which does not comply with these terms.

As we know from history, the new generation will always have more than any previous generation in every field, including new knowledge, especially technical knowledge, skills and abilities. In the mid-twentieth century, the development of science, technics and technology were processed as evolutionary and gradual. Therefore, the level of scientific progression of successive generations up to this point was not so different. However, by the second half of the twentieth century, scientific and technological progress has reached a high level and is rapidly developing. This requires from today's generation deep knowledge, skills and habits, as well as self-improvement. Because future technology is replacing tomorrow with a more sophisticated technological innovation.

At the same time, the Decree of the President of the Republic of Uzbekistan dated July 27, 2017 № PD-3151 "On measures to further increase the involvement of branches and sectors of the economy in improving the quality of higher education specialists" defines the goals, objectives and directions of educational activities. The implementation of these tasks depends, first of all, on the teacher, his or her level of knowledge and professionalism. How the teacher performs the tasks 
assigned to him or her with conscientious, intelligent, and professional skills is an important factor that ensures the future of society.

Strengthening the material and technical base and information background of higher education institutions, further improving the quality of effective training activities on the basis of high quality educational literature, modern teaching methods, and educational technologies are becoming more important. That is why one of the most important requirements of today is to further improve the professional skills of teachers, to organize training sessions using educational technologies in the educational process.

This article demonstrates the organization and implementation of teaching methods in mathematics based on the educational technology in higher education institutions of the Republic, using the comparative analysis of educational institutions of foreign countries and universities.

It should be noted that the role and importance of problem-based teaching in improving the methodology of effective teaching of mathematics are one of the factors that contribute to the increase of students' participation in the lessons.

At this point, it is important to focus on the content and essence of problem-based teaching. Problem-based teaching is based on the ideas of John Dewey, an American philosopher, psychologist and educator. J. Dewey and Bruner believed that the main purpose of teaching was to develop logical thinking.

At the beginning of the 20th century, American philosopher, psychologist and educator John Dewey proposed his own didactic system that was in contradiction to Gerbart's didactic system and tested it in a Chicago school. John Dewey argues that a student, not a teacher, should be active in the classroom, and that the knowledge provided in the lesson is consistent with the needs of the students and he thinks that memorizing the knowledge of the book in vain will not lead to anything, but will discourage the students from reading and blunt their thinking.

John Dewey's main contribution to education is "a complete process of reasoning". This is because the leading circle of the whole process of reasoning is the emergence of the problem. Once the problem has arisen, the student gets in trouble, seeks out its solution, and after a series of considerations, he finds and tries to solve the problem, and again, if he is wrong, re-evaluates it and after a few repetitions of the process, it eventually finds its solution. As a result, a complete process of thought is realized, and later such a didactic system has become known as a problematic lesson [2; Page 66.].

Indeed, the math learning process has its positive effect on the perfect mastering of math only if the "full process of reasoning" is represented by the students. For example, at the beginning of the lecture, problem-based questions are raised and according to students respond to them the new topic will start and during the lesson the student will understand what the issue is.

As a result of psycho-pedagogical research on problem-based teaching in order to develop students' creative thinking, a common technology of problem-based teaching was developed. In other words, V. Okono concludes that teaching is "a unit of problem-solving, expression the problem with words, helping students solve problems, checking their solutions, and guiding them in systematizing and consolidating the acquired knowledge."

It is important to recognize that during math teaching, a teacher can increase student activity in the classroom by expressing a topic problem in words. Based on this, I.Y. Lerner argues that the essence of teaching is that the student participates in the guidance of the teacher in solving new educational and practical problems that are new to him.

In our view, problem-based teaching refers to the learning process that involves the organization of independent activities aimed at creating and resolving problematic situations in the minds of students under the guidance of a teacher during the course of teaching. As a result of this process, knowledge acquisition, creative acquisition of skills and the development of students' thinking are achieved.

The effective organization of math classes goes through a number of stages as the perceptual activities associated with solving the student's problematic situations.

The first step is to see, formulate and express the problem. In order for the problem to function as an impulse, it must be accepted as a subject of the solution, which requires only some initial information, knowledge, abilities and so on. The availability of intellectual tools to carry out operations on the subject matter of the situation is possible. Only then the problem will be reversed to the extent of the problem. From this point of view, the ability of the teacher to see and reformulate the problem in the course of the training can be seen as one of the important qualities of a modern mathematics teacher. 
The second step is understanding and accepting the problem. This phase begins with the process of articulating the problem. In order to solve it, it is necessary to define the problem itself: what are its conditions, what is known, whether this problem has not been encountered before, whether there is a similar or related problem, and whether there is a need to add auxiliary elements to make use of the previous problem; can the problem be described differently, and so on?

The third stage is researching. The students move forward in their thinking, feeling their sequence of actions partially reflects the solution to the problem. As a result, ideas and hypotheses about the principles of problem-solving emerge on the basis of other problem-solving skills, existing knowledge and intuitive thinking. Among many such propositions, the student chooses a hypothesis. The student's cognitive or learning activity becomes more active in the search for the right hypothesis related to the promotion of propositions, which include debates and conclusions.

The study shows that students having experience of independent activities do analyticsynthetic thinking: problem solving begins with the data of the problem and continues until the next steps of the solution are clear. Then synthesis occurs. According to Yu.N. Klutik, SL Rubinstein, A.M. Sohor and others, at this stage, re-expression of the terms and conditions of the problem is carried out. As a result of re-expression, the problem is re-perceived, which leads to the discovery of new relationships and new connections between the elements of the problem.

The fourth stage is controlling. By distinguishing between unnecessary actions and necessary ones, useful actions and useless ones, the student represents the problem at this stage. During the controlling phase, the general hypothesis is corrected, refined, and categorized. The initial idea is transformed into a hypothesis that is specific to a particular solution method.

The basic objectives of problem-based teaching can be clarified in the effective organization of training sessions based on the stages of addressing the student's problematic situations discussed above. That is:

the acquisition of knowledge, skills, abilities by the learners;

increasing firm knowledge;

development of independent activities;

formation of research skills and abilities;

development of cognitive and creative abilities.

At the same time, the student has a number of difficulties related to performing certain actions in solving the problem of mathematics. Specifically:

actualization of a group of problems, including a defined component of the problem;

selecting from the problem group what is needed for its solution;

detecting the event of the problem by its signs and symptoms;

defining the features expressed in the problem, and so on.

In problem-based teaching, learning content is organized as a set of problematic situations. The best way is to include problematic situations in the traditional description of the teaching material.

From this, Kudryavtsev considers the essence of problem-based teaching as a didactic problem for students, its solving and mastering of generalized knowledge and principles of problem-solving, while Makhmutov considers that problem-based teaching is a developing form of teaching, he also considers a combination of systematic independent research activity of students and the development of readable conclusions in the subject.

Summarizing the above, it is worth noting that one of the main factors of effective organization of teaching process in higher education today is the improvement of the methodology of efficient organization of the learning process in mathematics.

Pedagogical and psychological aspects of the organization of teaching activities that contribute to the effective organization of the educational process in higher education are given in the works of the scientists of the our Republic such as M.G. Davletshin, E. Goziev, P.T. Magzumov, F.R. Yuzlikaev, Sh. Sharipov and others from CIS M.I. Makhmutov, V.A. Slastenin, V.S. Lednev and others. On studying the methodological aspects of teaching mathematics to students in educational institutions are given in the works of scientists of our Republic J.I. Ikromov, N.R. Gaybullayev, T. To'laganov, T. Tojiev, G.V. Zlotsky, S. Alikhanov, M. Raemov, D. Yunusova, N.Eshpulatov, Ch. Mirzaev and others, in the CIS were researched by Y.I. Kalyagin, Y.N. Makarichev, A.A. Stolyar, V.I. Mishin, V.S. Cherkasov, A.G. Mordukovich, G.I. Sarantsev and others. Research works on the organization of training courses for students in higher mathematics in higher education institutions are 
done by a number of Uzbek scholars, such as T.A. Azlarov, H.T. Mansurov, A. Sadullaev, G. Khudoyberganov, R. Gulomov, X.R. SHokirova X. and others.

The evidence from the authors of the above studies shows that students studying in higher education have a deep knowledge of mathematics, they are well acquainted with pedagogical situations, teaching methods, but at the same time there is no method of teaching mathematics lessons based on modern technology and teaching methods.

In this regard, to study and analyze the current state and psychological aspects of mathematics teaching in higher education institutions, and to determine the specifics of the organization of mathematics lessons using modern teaching methods and techniques; to develop a classification of the topics of math lessons and, based on this, to draft specific topics of math lessons; to create a new generation of educational-methodical complex, which is the basis for the organization of practical activities in mathematics; to develop and implement the methods of organization of mathematical studies using educational technologies and modern methods of teaching can be considered as the basis for high-level organization of math classes in higher education institutions.

\section{REFERENCES}

1. The Decree of the President of the Republic of Uzbekistan dated July 27, 2017 № PD-3151 "On measures to further increase the involvement of branches and sectors of the economy in improving the quality of higher education specialists"

2. Ziyomuhammadov B., Tojiev M. Pedagogical Technology - Modern Uzbek National Model // Tashkent: "Ishonch MS", 2009

3. Zulfiharov I.M. The importance of teaching mathematics using information technology based on an electronic didactic complex of educational tasks // APNI, trends in the development of modern natural sciences and technical ones, Belgorod. -2017. -№ 1. p.24-26.

4. Jan Amos Komensky. Great Didactics // T.: "Teacher", 1966

5. Ilhomjon M.Zulfiharov Methods of Organizing Mathematics Classes // Eastern European Scientific Journal // AURIS - Dusseldorf-Germany. -2018. -№ 3. 345-349 p.

6. Pimbley G. "Periodic solutions of predator-prey equations simulating an immune response" J.Math.Biolci, 1974, v.20, p.27-51. 